\title{
COTTON FABRIC DYEING WITH NATURAL COLORANTS EXTRACTED FROM BANANA PEEL
}

\author{
SALEH, S.M. ${ }^{1}$, Y.A. ABD-ELHADY ${ }^{1}$ AND M.M. FARAG ${ }^{2}$
}

1. Cotton Research Institute, ARC, Giza

2. Biochemistry Department, Faculty of Agriculture, Cairo University, Giza

(Manuscript received $1^{\text {st }}$ September 2008)

\begin{abstract}
This Work aimed to use pigments extracted from banana peel as natural waste source to dye some Egyptian cotton fabrics. Alkaline extracted solution using $0.1 \% \mathrm{NaOH}$ was analyzed by high performance thin layer chromatography (HPTLC), analysis technique. The alkaline solution was applied to the premordated bleached and mercerized cotton fabrics made from Giza 89 and Giza 83 cotton varieties. Ferric chloride, copper sulphate and potassium dichromate were used as mordents. The factors affecting the fixation of the extracted dye with cellulose was studied. The treated and untreated fabrics samples ware tested for their mechanical properties expressed as tensile strength ( $\mathrm{g} / \mathrm{tex}$ ) and elongation \%. Dyeing performance in terms of color parameters $\left(\mathrm{K} / \mathrm{S}, \mathrm{L}^{*}, \mathrm{a}^{*}, \mathrm{~b}^{*}\right.$ and $\left.\Delta \mathrm{E}\right)$, and fastness properties (wash, perspiration, and light fastness) were studied. The samples show high tensile strength, high color strength, and high fastness properties. These results are very important for industrial application with the production of a natural dye as an inexpensive source from banana peel as a by product. Another objective is to increase the production of eco-textile garments with a good price for the Egyptian customers .
\end{abstract}

\section{INTRODUCTION}

The use of synthetic dyestuffs during their application in the dyeing and printing industries has been criticized due to introduction contaminants into the environment, ( Lokhande et al, 1999). The beginning of the new millennium is sure to bring about many drastic changes in the life of mankind. One of them is going to be the shift towards natural dyes and their efficient usage compared to synthetic counterpart which have been slowly losing, mainly due to international awareness to environment and ecology preservation,( Bhattacharya et al. , 2002). Calls for the use of natural dyes on textiles has been just one of the consequences of increased environmental awareness, (Chavan .1998). The use of natural dyes for the coloration of textiles has mainly been confined to craft dyes and printers. Recently, more interests have been devoted to the use of these dyes and a limited number of commercial dyes and small business have started to look at the possibilities of using natural dyes for dyeing and printing of textiles, (Das .1992). 
Natural dyes are less toxic, non pollutant, less health hazard, very brilliant, rare color idea, and allergic reactions, ( Katyaynini and Jacob , 1998; Gupta et al. , 1998 and Mehra, 1994).

The annual cultivated area from banana plant in Egypt was about 62000 feddans in 2007. It gave about 464000 tons dry matter (about 1116000 tons fresh weight) of banana by products. These by products are collected from the field and burned after being sun dried, causing environmental pollution.

The determination of pigments in banana peel has assumed increasing importance with the recognition that those fruit part, are often a source of unique phenols or compounds in much higher concentration than in the flesh. Chemical treatment of banana peel and leaves may be suitable for natural dye extraction used from textile dyeing. Banana pigment contents were measured by colorimetric method. Zafari et al.( 1998), reported the endogenous levels of four cytokininis, as well as, the indolacetic acid, abscisic acid, chlorophylls, and carotenoids pigment of banana. Banana pigment was extracted and measured as described by (Lichlenthaler, 1987). The application of dye extracted from banana peel on mordant cotton and silk was described by (Inderpal, 2005).

An investigation was undertaken to gain some knowledge of the total yellow pigments in banana peel (Von Loesecke, 1929). The two xanthophylls and carotene were determined. Xanthophylls plus carotene remain approximately constant throughout the maturation of the fruit; therefore the yellow color of an unripe banana is masked by chlorophyll. The amount of xanthophylls is always greater than the amount of carotene, the range of the former being from about 5 to $7 \mathrm{mg} / \mathrm{k}$ of fresh peel, whilst the range of the latter is from 1.5 to $3.5 \mathrm{mg} / \mathrm{k}$ of fresh peel.

In relation to banana ripening, banana peel was examined for carotenoid pigments by a combination of alumina column chromatography and HPLC (Subagio et al., 1996). Carotenoids and their fatty-acid esters were first separated by an alumina column into five fractions, of which each was further subfractionated by HPLC with different kinds of solvent. The carotenoid content of the banana peel was in the range of 3-4 micrograms per gram as lutein equivalent. The ingredients of the carotenoids were ascertained to consist of lutein, beta-carotene, alpha-carotene, violaxanthin, auroxanthin, neoxanthin, isolutein, beta-cryptoxanthin and alpha-cryptoxanthin. Most of the oxygenated carotenoids were found to occur in the esterified form, mainly with myristate, and to a lesser extent with laurate, palmitate or caprate.

Simmonds,(1954) mentioned that the banana peel pigments were extracted with $1 \%$ hydrochloric acid and examined in the test-tube and by paper chromatography. Bate-Smith,(1949, 1950) described that the thin layer chomatography analysis of anthocyanidins extracted pigment from banana peel by Forestal solvent (conc. Hydrochloric acid $(\mathrm{HCl})$ - acetic acid $(\mathrm{HOAc})$ - water $\left(\mathrm{H}_{2} \mathrm{O}\right)$ (3: 30: 10) followed by $\mathrm{n}$ butanol-2N hydrochloric acid. Banana peel extract composition and method for 
extraction were descibed by (Bobby, 2000). TLC and HPTLC are simple, sensitive and less subject to interference by coextractives than HPLC. Two dimensional thin layer chromatography has greatly improved the separation ability of the thin layer techniques. However, one should take into account that the presence of a spot on the TLC/HPTLC plate can only be considered as presumptive evidence of identification, and further confirmation tests are required. Although several HPLC methods have been developed for AFM analysis and by immunoassay still TLC methods can be recommended when no HPLC equipment is available, (Scussel, 2003).

The objective of this study is to produce a natural dye as an inexpensive source from banana peel as a waste and to increase the production of eco-textile garments with a good price for the Egyptian customers.

\section{MATERIALS AND METHODS}

\section{Materials}

Unbleached long staple Egyptian cotton fabrics made from Giza 83, and Giza 89 were purchased from Misr-El-Mehala Company for Spinning and Textile- Egypt. The fabrics have the following specification: plan weaved, wrap 36 yarn/cm, weft 30 yarn/cm, and fabric weight $150 \mathrm{~g} / \mathrm{m}$. All chemicals used were of analytical grade using doubly distilled water (18.5 M' $\Omega . \mathrm{cm}^{-1}$ ). NaOH was analytical grade (Koch-Light Co.), Hydrogen peroxide ( $30 \%$ LR grade) from Aldrich. Sodium carbonate (LR grade), sodium silicate $\left(136{ }^{\circ} \mathrm{Tw}, 27 \% \mathrm{SiO}_{2}\right)$, the wetting agent was the commercially Ttiton 100 supplied by Merck. Acetontrile, formic acid were of HPLC grade.

\section{Scouring, bleaching and mercerizing treatments}

Scouring of the fabric samples was performed by the pad-steam technique by padding the fabric with $3 \% \mathrm{NaOH}$ containing $1.5-2 \%$ of the wetting agent in a twobowel padding mangle adjusting the squeeze pressure to enable $100 \%$ wet pick-up of the fabric and subsequently steamed in a laboratory steamer at $100{ }^{\circ}$, for 10 minutes. The scoured fabric was washed with water, neutralized with dilute acetic acid, further washed with water, and finally dried in air.

The scoured fabrics were immersed in alkaline bleach liquor (180 $\mathrm{ml} \mathrm{dH2O})$, containing $\mathrm{Na}_{2} \mathrm{CO}_{3}(0.2 \mathrm{~g} / \mathrm{l})$, $\mathrm{NaOH}(1.5 \mathrm{~g} / \mathrm{l}), \mathrm{SiO}_{2}(0.4 \mathrm{~g} / \mathrm{l}), \mathrm{MgSO}_{4}(0.2 \mathrm{~g} / \mathrm{l})$, Triton 100 $(0.5 \mathrm{~g} / \mathrm{l})$, and $\mathrm{H}_{2} \mathrm{O}_{2}\left(10 \mathrm{ml}^{-1}\right)$ were added to the bleaching liquor. The samples were removed from the liquor and neutralized with aqueous solution containing $0.1 \%$ acetic acid followed by a through hot water $\left(80-85^{\circ} \mathrm{C}\right)$ to ensure removal of residual chemicals. Samples were dried in an oven at $100^{\circ} \mathrm{C}$, for 60 minutes.

The bleached fabrics were treated with aqueous solution of $\mathrm{NaOH}(20 \%)$, at room temperature. The samples were then subjected to final treatment applying the same procedure for the scoured fabrics. 


\section{Banana peel pigments extraction}

About $100 \mathrm{~g}$ of the banana peel that contains the dye component was cut to small pieces and boiled in one litre in a solution of $0.1 \% \mathrm{NaOH}$ and concentrated to $500 \mathrm{cc}$. The slurry was left to react for a period of time wherein a yellow supernatant forms at the top. This yellow supernatant changes to amber and then to an opaque black as the reaction proceeds. The entire slurry was then filtered and any solid material discarded. The extracted liquor was used as the foundation of the dye.

\section{Dyeing bath of the fabric samples}

The cotton fabrics were dyed using the banana peel extraction liquor in the dyeing bath at $80{ }^{\circ} \mathrm{C}$ for 90 minutes under stirring conditions. The $\mathrm{pH}$ of the dye was adjusted to 9. After completion of dyeing, the fabrics were washed with water and air dried.

\section{Evaluation the properties of the treated fabrics}

\section{Measurement of the dyeability}

The color strength $(\mathrm{K} / \mathrm{S})$ of the treated samples using the untreated samples as blank was determined using Perkin Elmer Spectrophotometer, Model Lambda 35 equipped with integrated sphere with applying the Kubelka-Munk equation:

$$
K / S=\left[(1-R)^{2} / 2 R\right]
$$

The color parameters L*(lightness-darkness), a*(red-green), $\quad b *$ (blue-yellow component), $\mathrm{R} \%$ (reflectance), and $\Delta \mathrm{E}$ were measured by using the Win lab software CIE TC1-29 proposed color difference equation.

\section{Tensile properties}

The tensile strength ( $\mathrm{g} / \mathrm{tex}$ ) and elongation (\%) were measured according to ASTM D412-98a using Zwick testing machine of model Z010 and equipped with 10Kn load cell and the testing was conducted at speed of $100 \mathrm{~mm} / \mathrm{min}$. The results obtained were based on an average of ten tests in the wrap direction of each sample.

\section{Fastness properties}

Washing fastness (WF)

Washing fastness of the untreated samples was done according to ISO 105-C01:1998(E). Two single fiber adjacent fabrics complying with the relevant sections of F01 to F08 of ISO 105-F: 1989. One adjacent fabric of cotton and the second of wool.

(b) Perspiration fastness(PF)

Fastness to synthetic perspiration was measured according to ISO-E04: 1994.

(c) Light fastness

Fastness of light was measured according to the ISO 105:1997 using standard wool serge as reference in all testes. 


\section{High performance thin Layer chromatographic analysis (HPTLC)}

A CAMAG TLC system comprising of a Linomat-5 applicator, CAMAG TLC scanner and single pan balance of Shimadzu model was used, for the present study. Stationary phase used was silica gel $\mathrm{G}_{60} \mathrm{~F}_{254}, 20 \times 10 \mathrm{~cm}$ TLC plate activated at $75^{\circ} \mathrm{C}$ for 20 mins, the mobile phase used was forestal solvent conc. $\mathrm{HCl}-\mathrm{HOAC}-\mathrm{H}_{2} \mathrm{O}$ (3: 30: 10). The plates were developed by ascending method in a CAMAG twin trough glass chamber $(20 \times 10 \mathrm{~cm})$ saturated with filter paper for 10 mins. Distance of solvent front $80 \mathrm{~mm}$, band length $8 \mathrm{~mm}$, slit dimension $6.00 \times 0.30 \mathrm{~mm}$, detection wavelength $254 \mathrm{~nm}$, temperature $26.4^{\circ} \mathrm{C}$ and humidity $61 \%$ were used for the present study.

Banana peel crude extract was used as stock solution spotted on precoated TLC plates using Linomat 5 applicator, plates were developed and scanned using CAMAG TLC scanner 3. The plate was developed and the spots were scanned, peak, height, areas and $R_{f}$ values were measured.

\section{RESULTS AND DISCUSSION}

The main objective of the present study was to characterize the pigment compound Luteolin, which exists in the banana peel crude alkaline extract. The structure of this compound is shown in Figure 1.<smiles>O=c1cc(-c2ccc(O)c(O)c2)oc2cc(O)cc(O)c12</smiles>

Luteolin

Figure 1. Structure of the banana peel crude alkaline extracted compound

Luteolin is one of the more common flavones most often found in leaves, but it is also present in rinds, barks, clover blossom and ragweed pollen ( Kerley et al., 1988 ).

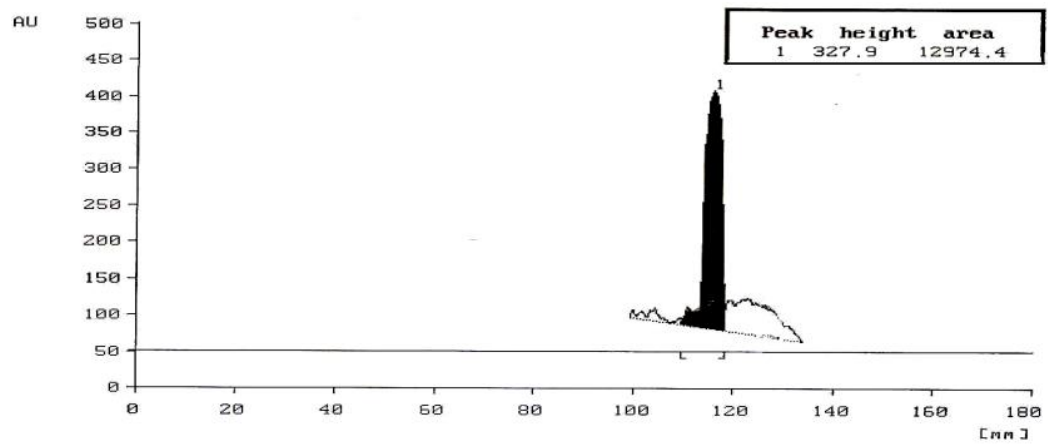

Figure 2. HPTLC chromatogram of the banana peel crude extracted 
The spectral data presented in Figure 2 show the maximum absorption for the chromatographic peak as luteolin, peak height as 327.9 , peak area as 12974.4 , and Rf as 66.

Table 1 shows fabric tensile strength and elongation\% for scoured, bleached and mercerized Giza 83, and Giza 89. It has been noted that both the two fabrics control (raw material) had higher tensile strength among the unmordanted fabrics. This is due to the damage effect of the scouring or the bleaching agents on the tensile strength of the fabrics ${ }^{23}$. The addition of the mordents increases the tensile strength for the two fabrics due to the complex formation of the metals with the free hydroxyl ions of cotton. The results obtained showed maximum value of tensile strength by the addition of $\mathrm{Cr}$, and minimum value by the addition of $\mathrm{Cu}$. The scoured, bleached, and mercerized fabric samples showed higher tensile strength than the scoured and bleached fabric samples, and Giza 89 also shows increase in tensile strength than that of Giza 83. On the other hand, both the two fabrics control (raw material) had higher elongation $\%$ among the unmordanted fabrics. This is due to the damage effect of the scoured or the bleached agents on the elongation $\%$ of the fabrics. The addition of the mordents decreases the elongation $\%$ for the same reason. The results obtained showed maximum value of elongation $\%$ by the addition of $\mathrm{Cu}$, and minimum value by the addition of $\mathrm{Cr}$. The scoured, bleached, and mercerized fabric samples showed lower elongation\% than the scoured and bleached fabric samples, and Giza 89 also shows decrease in elongation\% than that of Giza 83.

Table 1. Mechanical properties of cotton(Giza 83) and (Giza 89) pretreatment scouring, bleaching and mercerization dyed with banana peel extract

\begin{tabular}{|c|c|c|c|c|}
\hline \multirow{2}{*}{ Method } & \multicolumn{2}{|c|}{ Tensile strength } & \multicolumn{2}{|c|}{ Elongation (\%) } \\
\hline & $\mathrm{I}$ & II & $\mathrm{I}$ & II \\
\hline Control* & 40 & 45 & 3.6 & 3.4 \\
\hline Unmordant* & 39 & 43 & 2.9 & 2.8 \\
\hline $\mathrm{Fe}^{*}$ & 45 & 51 & 2.4 & 2.0 \\
\hline Cu* & 44 & 47 & 2.7 & 2.2 \\
\hline $\mathrm{Cr} *$ & 49 & 57 & 2.4 & 2.0 \\
\hline Control** & 45 & 55 & 3.0 & 3.0 \\
\hline Unmordant** & 42 & 45 & 2.9 & 2.6 \\
\hline $\mathrm{Fe}^{* *}$ & 50 & 57 & 2.8 & 2.0 \\
\hline $\mathrm{Cu}^{* *}$ & 49 & 55 & 2.9 & 2.2 \\
\hline $\mathrm{Cr} * *$ & 54 & 65 & 2.0 & 1.2 \\
\hline
\end{tabular}

* Pretreatment Scouring and Bleaching

** Pretreatment Scouring, Bleaching and Mercerization

I Giza 83 , II Giza 89 
Table 2 shows K/S (measure of color strength), R\% (reflectance), L* (lightnessdarkness), a* (red-green), b* (blue-yellow component) and total color difference $(\Delta E)$ of the scoured, bleached and scoured, bleached and mercerized of both Giza 89, and Giza 83 cotton fabrics before and after mordanting treatment. The results obtained revealed that there were a higher K/S values for both mercerized Giza 89, and 83 samples. However, the mordanted samples had a higher K/S values than the unmordanted samples. Giza 89 cotton samples shows a higher $\mathrm{K} / \mathrm{S}$ values than those of Giza 83 at all conditions. It has been noted that mordanting with iron gave a maximum $\Delta \mathrm{E}$, which is mainly attributed to the lower values of $L^{*}$, due to the high stability formation of the complex between the $\mathrm{Fe}$ and luteoline as a phenolic compound. The results obtained revealed that the values of $L^{*}, a^{*}$, and $b^{*}$ have been changed by the addition of the mordents which shift the color of the dye due to the reaction between the metal ion and luteoline. When the comparison was made between the unmordanted and the mordanted shades. It was observed that iron gave a stronger yellowish brown, while $\mathrm{Cu}$ produced a greener color, and $\mathrm{Cr}$ produced a very fade yellow color.

The results listed in Table 3 illustrate the effect of various mordants on the fastness properties of Giza 83, and Giza 89 cotton fabrics. When the dyeing after mordanting were compared with the unmordanted samples, it is clear that the mordanted fabrics showed a slight fastness improvement. It is evident that, the stronger the dye-fiber bond, the easier is the transfer of the excitation energy from the dye molecule to the fiber macromolecular chain. Thus, the dye -fiber bond serves as a bridge for transferring the excitation energy between the two components of the dye fiber ambient system. If this bond promotes the energy transfer, the light fastness increases. There were no significant difference of the fastness properties for all Giza 83 and Giza 89 fabric samples.

\section{CONCLUSION}

The use of pigments extracted by alkaline solution using $1 \% \mathrm{NaOH}$ from banana peel as natural waste source to dye some Egyptian cotton fabrics has been achieved. The treated and untreated fabrics samples ware tested for their mechanical properties expressed as tensile strength $(\mathrm{N} / \mathrm{cm} 2)$ and elongation \%. Dyeing performance in terms of color parameter $(K / S, L, a, b$ and $\Delta E$ ), and fastness properties (wash, perspiration, and abrasion) were studied. The samples show a high tensile strength, high color strength, and high fastness properties. We believe that the results obtained here are interesting for industrial application due to the production of a natural dye as an inexpensive source from banana peel as a by product. Another objective is to contribute in solving or decrease the problem of burning banana peel, causing Environmental pollution. 
Table 2. Color measurements of cotton (Giza 83) and (Giza 89) fabrics: pretreatment scouring, bleaching and mercerization dyed with banana peel extract

\begin{tabular}{|c|c|c|c|c|c|c|c|c|c|c|c|c|}
\hline \multirow{2}{*}{ Method } & \multicolumn{2}{|c|}{$\mathrm{K} / \mathrm{S}$} & \multicolumn{2}{|c|}{$\mathrm{R} \%$} & \multicolumn{2}{|c|}{$L^{*}$} & \multicolumn{2}{|c|}{ a* } & \multicolumn{2}{|c|}{$b^{*}$} & \multicolumn{2}{|c|}{$\Delta \mathrm{E}$} \\
\hline & I & II & I & II & I & II & I & II & I & II & I & II \\
\hline control* & 0.1 & 0.12 & 66.07 & 61.58 & 85.7 & 83.45 & -0.17 & -0.13 & -1.21 & -1.69 & 14.36 & 16.65 \\
\hline Unmordant* & 0.42 & 0.52 & 41.21 & 37.42 & 75.82 & 77.01 & 0.9 & 0.52 & 7.1 & 5.6 & 25.2 & 23.63 \\
\hline $\mathrm{Fe}^{*}$ & 1.71 & 1.9 & 19.12 & 18.2 & 62.43 & 69.54 & 6.92 & 3.6 & 25.35 & 19.43 & 45.79 & 36.24 \\
\hline $\mathrm{Cu}^{*}$ & 1.12 & 1.7 & 25.01 & 19.6 & 64.3 & 68.1 & -2.54 & -3.1 & 16.13 & 16.4 & 39.18 & 35.9 \\
\hline $\mathrm{Cr} *$ & 0.26 & 0.36 & 49.5 & 44.32 & 81.84 & 79.1 & -1.1 & -1.12 & 3.6 & 4.5 & 18.5 & 21.4 \\
\hline control** & 0.13 & 0.14 & 60.26 & 59.3 & 81.77 & 82.4 & -0.19 & -0.01 & -0.65 & -1.12 & 18.24 & 17.64 \\
\hline Unmordant** & 0.52 & 0.62 & 37.7 & 34.5 & 74.2 & 76.7 & 0.7 & 0.4 & 7.3 & 6.99 & 26.82 & 24.33 \\
\hline $\mathrm{Fe}^{* *}$ & 2.96 & 3.99 & 12.84 & 10.11 & 60.3 & 68.94 & 2.95 & 4.81 & 78.2 & 21.67 & 41.63 & 41.71 \\
\hline $\mathrm{Cu}^{* *}$ & 1.5 & 1.8 & 21.1 & 18.5 & 70.6 & 64.62 & -1.99 & -4.1 & 12.42 & 12.1 & 34.7 & 33.5 \\
\hline $\mathrm{Cr} * *$ & 0.34 & 0.403 & 44.9 & 41.9 & 78.04 & 79.4 & -1.1 & -0.98 & 5.69 & 4.52 & 22.7 & 21.1 \\
\hline
\end{tabular}

* Pretreatment Scouring and Bleaching

** Pretreatment Scouring, Bleaching and Mercerization

I Giza 83 , II Giza 89 
Table 3. Fastness properties of cotton(Giza 83) and (Giza 89) fabrics: pretreatment scouring, bleaching and mercerization dyed with banana peel extract.

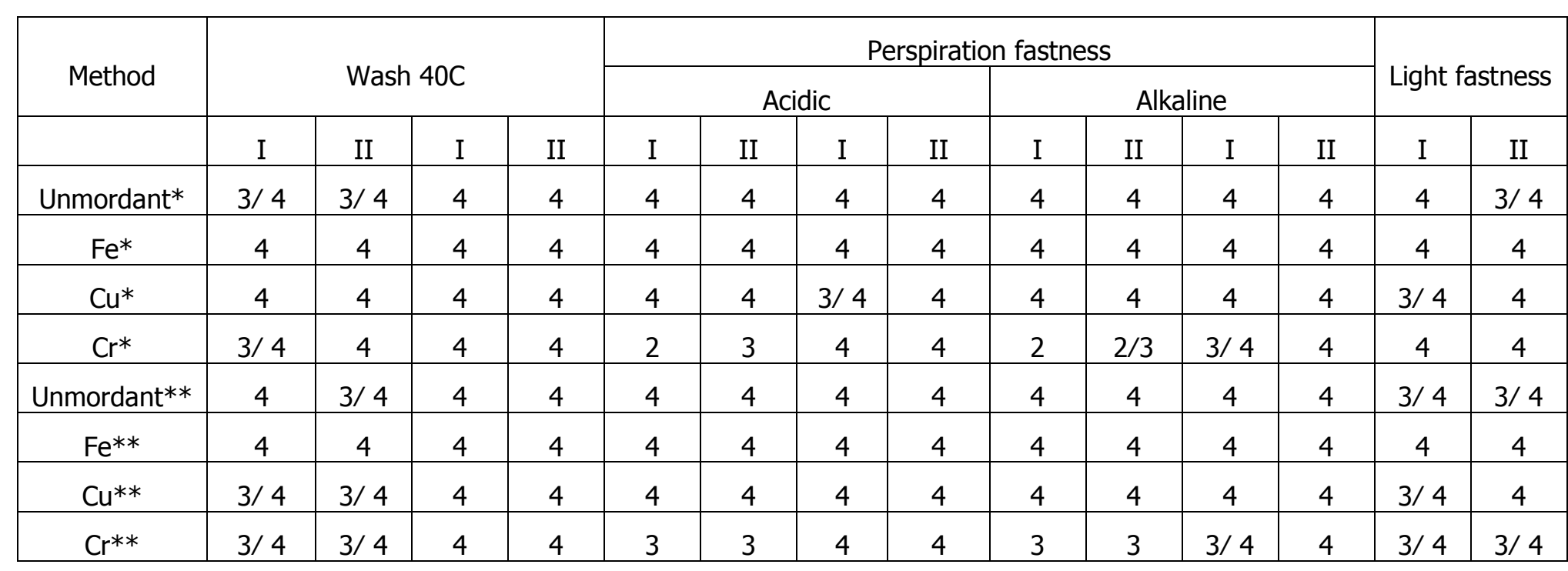

* Pretreatment Scouring and Bleaching

** Pretreatment Scouring, Bleaching and Mercerization

I Giza 83 , II Giza 89 


\section{REFERENCES}

1. Bate-Smith, E. C. and R. G. Westall. 1950. Biochim. et Biophys. Acta, 4, 427.

2. Bhattacharya, S.C. and Santhosm Mathew. 2002. Colourage. sept., 19-23.

3. Bobby, G., United States Patent $6013260,01 / 11 / 2000$

4. Chavan, R. B. 1998. Colourage , XLII. No.4, April. P 27.

5. Das, S. 1992. colorage, XXX1X, No. 9, sept., p.52.

6. Gupta, V.K., R. A. Sachon, V. P. Singh and V. P. Sharma. 1998. The Indian Textile Journal, 108, No.4,p.16.

7. Inderpal, R. 2005, Current science, 88, No. 9, 10 May, p. 1370.

8. Katyaynini, V. K. and M. Jacob. 1998. The Indian textile journal, 108, No.4, p. 86.

9. Kerley, M.S., K. A. Garleb, G.C.Fahey, Jr., L.L.Berger, K.J. Moore, G.N. Phillips and J.M. Gould. 1988. J.Anim Sci. 66: 3235- 3244.

10. Lichtenhaler, H. K. 1987. Methods Enzymol, 148, p. 350-382.

11. Lokhande, H.T. Vishnu A. Dorugade 1999. Amercian dyestuff Reporter, February, 29-34.

12. Mats Brune, Leif Hallberg and Ann-britt Skanberg 2006. Journal of food Science 56(1):128- 131.

13. Mehra, R. H. and A. R. Mehra. 1994. Colourage, XL1, No.12, p.25.

14. Subagio, A., N. Morita, S. Sawada. 1996. J. Nutr Sci Vitaminol (Tokyo). Dec. 42, No.6, p. $553-66$.

15. Simmonds, N. W. 1954. Nature 173, $402-403$.

16. Scussel, V.M., 2003. Cienc. Tecnol. Aliment., Campinas, 23 (Supl): 24-52, dez.

17. von Loesecke, H. 1929. J. Amer. Chem. Soc., 51, p. 2439-2443.

18. Zaffari, G.R., L.E.P. Peres and G.B. Kerbauy. 1998. J Plant Growth Regul. 17, p. 59- 61. 


\title{
صباغة قماش القطن بالالوان الطبيعية المستخرجة من غلاف ثمرة الموز
}

\author{
صلاح منصور صالح ' ، مصطفى محمد فرج 'بارئ

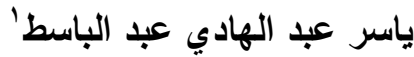

$$
\begin{aligned}
& 1 \text { - معرج بحوث القطن - مركز البحوث الزراعية - الجيزة } \\
& \text { r- كلية الزراعة - جامعه القاهرة - الجيزة }
\end{aligned}
$$

لاشك أن المخلفات الزراعية أصبحت تمثل عبئًا على كل من المزارعين والدولة في آن واحد حيث يصعب التخلص منها مما يضطر المزارعين إلى احراقها وهذا يؤدي إلى نلوث البيئة. ويعثبر هذا البحث اسهاما في حل هذه المشكلة وذلك باستخدام احد هذه المخلفات لانتاج صبغات طبيعية لصباغة المنسوجات القطنية المصرية المختلفة. تم في هذا البحث

1. استخلاص الصبغات الطبيعية من قثر الموز باستخدام تركيز ... هيدروكسيد صوديوم ثم

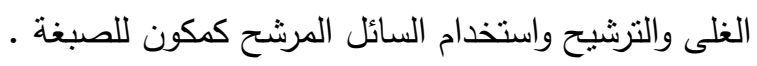
r. تم التعرف على المركب الكيميائي المستخرج من قتشر الموز وهي مادة الليتيولين(uteolin) وذللك

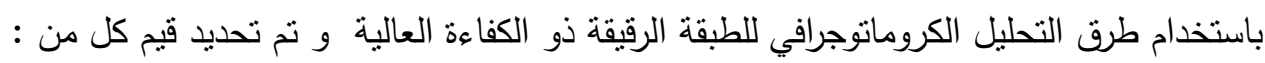
وارتفاع ومساحة قمم الامتصاص وقد تم تقدير درجة التردد الموجي للمادة المستخرجة باستخدام جهاز القياس الطيفي. r. تم صباغة اقمشة منتجة من صنفين من الأصناف القطنية وهما جيزة 19 وجيزة؟ نم تم الحصول

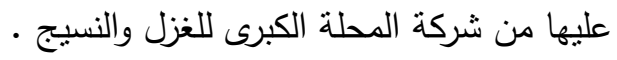
ع. تم استخدام كل من كلوريد الحديد وكبريتات النحاس وثاني كرومات البوتاسيوم كمواد مثبتة للصبغات على سطح الأصناف القطنية وبنسب محددة لا تتعدى الحد المطلوب بيئيا وعالميا

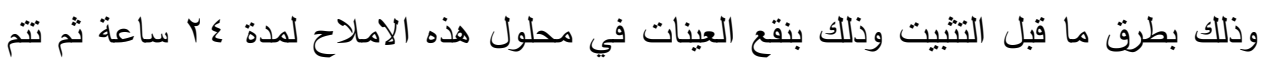

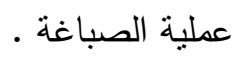

$$
\text { • • تم في هذا البحث الدراسات الاتية . }
$$

ا ـ دراسة ميكانيكية التفاعل بين الصبغة المستخرجة من قثر الموز والسليلوز وتأثير الاملاح المعدنية المضافة على هذا التفاعل . r. دراسة وقياس المتانة والاستطالة ( الصفات الميكانيكيه ) للأقشة المستخدمة قبل وبعد الصباغة وقبل وبعد اضافة المواد المثنتة. r. تم دراسة وقياس الخواص اللونية مثل درجة عمق اللون(K/S) والقياسات اللونية المختلفة ( (L*, a*) الايضا للأقشة القطنية قبل وبعد إضافة الأملاح المعدنية. 
ع. تم دراسة وقياس صفات الثبات للضوء - العرق - للغسيل - للعينات المستخدمة قبل وبعد اضافة

$$
\text { وقد أظهرت التجارب المعدنية. }
$$

ا. أن قيم الاستطالة والمتانة قد تتاقصت بعد عمليات التبيض والغليان عن المقارنة وذلك بتأثير

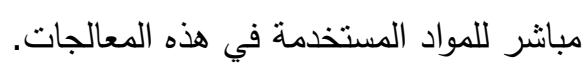

r. أن إضافة الأملاح المعدنية للأصناف اظهرت تحسنا كبيرا في صفات المعال المناتة الماتة والاسنطالة لهذه

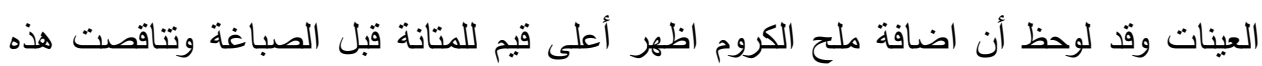

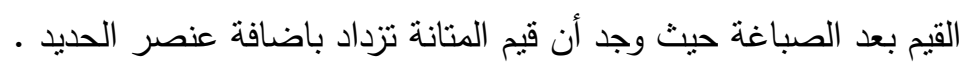

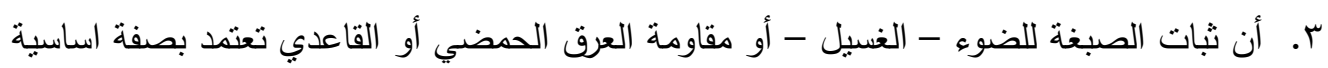

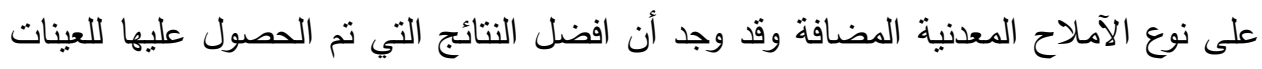

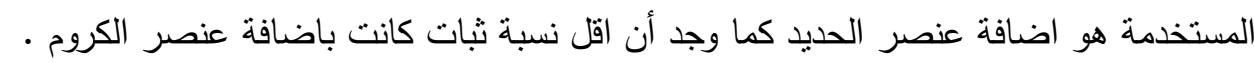

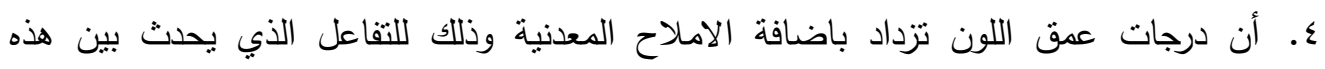

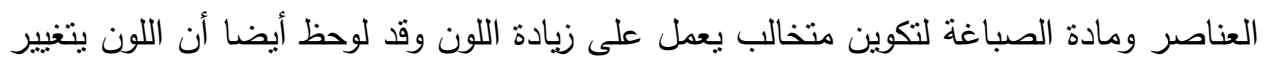

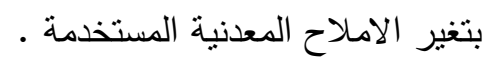

0. أن العينات المستخدمة من صنف جيزة 19 اعطت قيم أعلى من قيم صنف جيزة به المستخدم في هذا البحث كما وجد أن العينات المحرة ( الممرسرة ) اظهرت اعلى نتائج في كل القياسات

$$
\text { الخلاصة: }
$$

1. التخلص من المخلفات الزراعية عن طريق استخدمها في صباغة المنسوجات القطنية

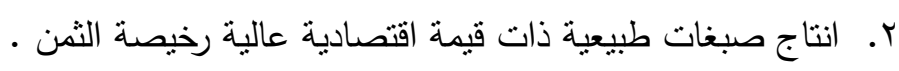

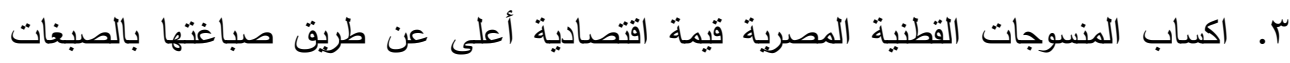

$$
\text { الطبيعية عن المنسوجات المصبوغة بالصبغات الصناعية . }
$$

ء. الحفاظ على البيئة نتيجة التخلص من المخلفات الزراعية بطريق امنة ونظيفة .

ه. إنتاج ألوان مختلفة باضافة الأملاح المعدنية بنسب لا تتعدى الحد المسموح به عالميا. 